\title{
Rhinovirus-Infected Patients in the COVID-19 Pandemic Period
}

This article was published in the following Dove Press journal:

Infection and Drug Resistance

\author{
Yuji Watanabe iD ${ }^{1,2}$ \\ Yasuhiro Kamiokal,3 \\ Masafumi Seki iD \\ 'Division of Infectious Diseases and \\ Infection Control, Tohoku Medical and \\ Pharmaceutical University Hospital, \\ Sendai City, Miyagi, Japan; '2Laboratory \\ for Clinical Microbiology, Tohoku Medical \\ and Pharmaceutical University Hospital, \\ Sendai City, Miyagi, Japan; ${ }^{3}$ Department \\ of Pharmacy, Tohoku Medical and \\ Pharmaceutical University Hospital, \\ Sendai City, Miyagi, Japan
}

\begin{abstract}
Human rhinovirus (HRV) is known as one of the most important respiratory pathogens, and the clinical characteristics of HRV infection might be similar to those of coronavirus disease 2019 (COVID-19). We identified 11 HRV-infected patients by polymerase chain reactions of the HRV genes among 151 outpatients with fever. All nine adult patients had underlying diseases and finally improved with the appropriate treatment in this COVID-19 pandemic period. Differential diagnosis between HRV and severe acute respiratory syndrome coronavirus 2 (SARS-CoV-2) infection will be needed to save lives and medical resources.
\end{abstract}

Keywords: SARS-CoV-2, human rhinovirus, PCR, antimicrobial stewardship

\section{Commentary}

Since February 2020, the coronavirus disease 2019 (COVID-19) pandemic has been a huge issue in the world including Japan, and many clinics and hospitals have started polymerase chain reaction (PCR)-based surveillance of febrile patients and/ or patients with a history of close contact with COVID-19 persons and who visited a pandemic metropolitan area. ${ }^{1,2}$ In this pandemic era, the trends of the other respiratory viruses, including influenza (flu), respiratory syncytial virus (RSV), human metapneumovirus (hMPV), and human rhinovirus (HRV) may be important factors affecting the prevalence of severe acute respiratory syndrome coronavirus 2 (SARS-CoV-2), because virus-virus interference is well known. ${ }^{3}$

In our hospital, we identified $11 \mathrm{HRV}$-infected patients among 151 febrile outpatients from October 10 to December 25, 2020 (Table 1). These patients were initially suspected to have COVID-19, but SARS-CoV-2 infection was not detected by PCR-based surveillance (cobas SARS-CoV-2 test, Roche, Basel, Switzerland). ${ }^{4}$ We confirmed HRV infection using virus-specific primers (LightMix Modular Rhinovirus, Roche), ${ }^{5}$ and the patients showed the characteristic clinical features: all nine "adult" patients had underlying diseases, although the other three "pediatric" patients (Patients 5, 8, and 9) had been healthy. A variety of diseases were diagnosed, and bacteria, such as Escherichia coli, Streptococcus pneumoniae, and Staphylococcus aureus were isolated from some patients (Patients 2, 4, and 5), but they finally improved with the appropriate treatments, including antibiotics, such as meropenem, ampicillin/sulbactam, and cefazolin. Only one parainfluenza virus-infected patient was found (data not shown), but no other viruses, including Flu, RSV, hMPV, and SARS-CoV-2, were detected among the 151 febrile outpatients.
Correspondence: Masafumi Seki Division of Infectious Diseases and Infection Control, Tohoku Medical and Pharmaceutical University Hospital, I-12-

I Fukumuro, Miyagino-ku, Sendai City,

Miyagi, 983-86/2, Japan

Tel +8I-22-983-122I

Fax +8I-22-983-1232

Email m-seki@tohoku-mpu.ac.jp 


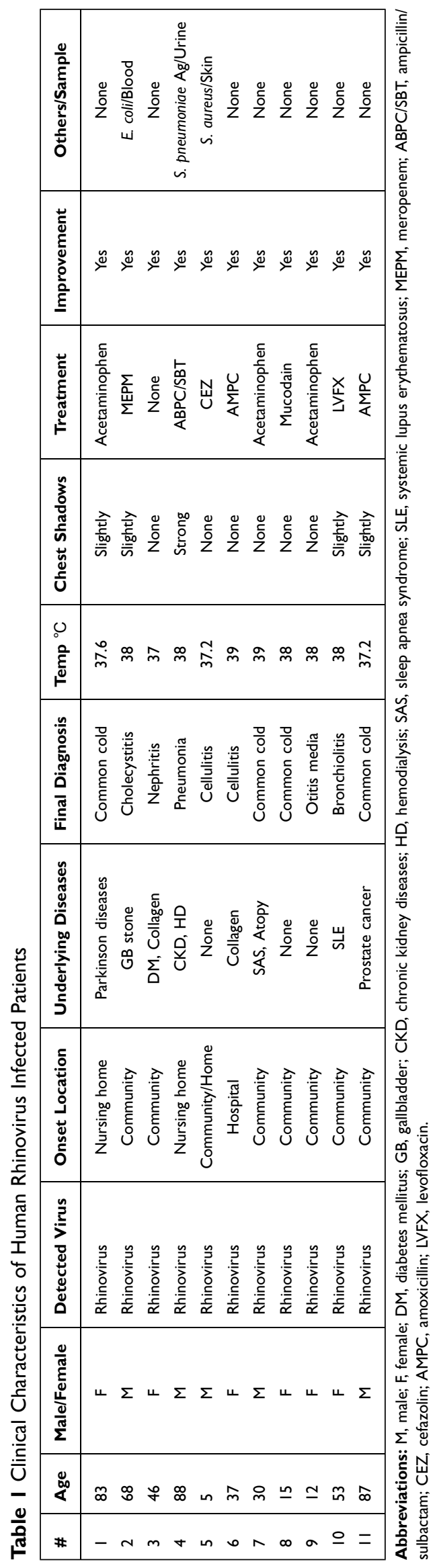

HRVs are known to be the responsible pathogens for more than half of the cold-like illnesses, and recently they have been found not only as upper respiratory tract pathogens, but also as lower bronchial tract pathogens, in particular, in patients with asthma, infants, elderly patients, and immunocompromised hosts. ${ }^{6}$ The symptoms, signs, and pathogenesis of HRV infection may be severe and similar to COVID19 in patients with underlying diseases. Therefore, accurate differential diagnosis is critical to save the patients and valuable medical resources, including antimicrobial agents, based on the antiviral stewardship philosophy. In addition, the development of antiHRV agents may also be needed to improve these patients' conditions quickly in the COVID-19 pandemic era.

\section{Ethics}

The analysis was approved by the Committee for Clinical Scientific Research of Tohoku Medical and Pharmaceutical University Hospital on May 21, 2017 (No. ID 2017-2-010), and the patients provided written, informed consent for use of their specimens, although the samples were collected as part of routine laboratory analyses.

\section{Disclosure}

The authors report no conflicts of interest in this work.

\section{References}

1. Yamagishi T, Ohnishi M, Matsunaga N, et al. Environmental sampling for severe acute respiratory syndrome Coronavirus 2 during a COVID-19 outbreak on the diamond princess cruise ship. J Infect Dis. 2020;222:1098-1102. doi:10.1093/infdis/jiaa437

2. Sugano N, Ando W, Fukushima W. Cluster of severe acute respiratory syndrome Coronavirus 2 infections linked to music clubs in Osaka, Japan. J Infect Dis. 2020;222:1635-1640. doi:10.1093/ infdis/jiaa542

3. Nickbakhsh S, Mair C, Matthews L, et al. Virus-virus interactions impact the population dynamics of influenza and the common cold. Proc Natl Acad Sci U S A. 2019;116:27142-27150. doi:10.1073/ pnas. 1911083116

4. Pujadas E, Ibeh N, Hernandez MM, et al. Comparison of SARS-CoV-2 detection from nasopharyngeal swab samples by the Roche cobas 6800 SARS-CoV-2 test and a laboratory-developed real-time RT-PCR test. J Med Virol. 2020;92:1695-1698. doi:10.1002/jmv.25988

5. Moesker FM, van Kampen JJ, van Rossum AM, et al. Viruses as sole causative agents of severe acute respiratory tract infections in children. PLoS One. 2016;11:e0150776. doi:10.1371/journal.pone.0150776

6. Jacobs SE, Lamson D, St George K, Walsh TJ. Human rhinoviruses. Clin Microbiol Rev. 2013;26:135-162. 


\section{Publish your work in this journal}

Infection and Drug Resistance is an international, peer-reviewed openaccess journal that focuses on the optimal treatment of infection (bacterial, fungal and viral) and the development and institution of preventive strategies to minimize the development and spread of resistance. The journal is specifically concerned with the epidemiology of antibiotic resistance and the mechanisms of resistance development and diffusion in both hospitals and the community. The manuscript management system is completely online and includes a very quick and fair peerreview system, which is all easy to use. Visit http://www.dovepress.com/ testimonials.php to read real quotes from published authors. 